\title{
LX. On the analysis of wine
}

\section{Chaptal}

To cite this article: C. Chaptal (1802) LX. On the analysis of wine, Philosophical Magazine Series 1, 11:44, 368-375, DOI: 10.1080/14786440208676009

To link to this article: http://dx.doi.org/10.1080/14786440208676009

$$
\text { 曲 Published online: } 18 \text { May } 2009 .
$$

Submit your article to this journal 전

LII Article views: 2

Q View related articles ¿ 


\section{$\left[\begin{array}{lll}368 & ]\end{array}\right.$}

LX. On tbe Analyfs of Wine. By C. Chaftat

[Concluded from p. 134]

Now

OW that we are acquainted with the faults in the conftruction of the diftilling apparatus, let us try to make an application of it in order to improve the knowledge we have acquired in regard to diftillation, and the art of managing the fire.

It appears to me that the whole art of diftilling may be reduced to the three following principles:

Ift, To heat at once, and in an uniform manner, all the points of the mars of the liquid.

$2 \mathrm{~d}$, To remove all thofe obftacles which may confine the afcent of the vapours.

3 d, To effect the condenfation as fpeedily as poffible.

To fulfil the firft condition, it will be neceflary that the mafs of the liquid thould have little depth; and this requires that the bottom of the boiler fhould prefent a very large furface, that the fire may be applied in a great many points.

The bottom of the ftill ought to be a little bent inwards. This form is attended with two advantages: the firt is, that by thefe means the fuel is at an equal diftance from every point of it, and that the heat is uniform throughout; the fecond is, that by this conftruction the bottom of the boiler bas more ftrength, and the matters which may be depofited at the bottom of the liquor are thrown to the angles which refit on the mafon work, and where, confequently, it is lefs dangerous. When this depofit falls upon parts immediately expofed to the direct action of the heat, it forms a cruft, which prevents the liquor from being in contact with the part of the boiler covered by it, and the fire then burns the metal. This inconvenience is not to be feared, if the depolit by the curved form of the bottom is thrown into the angles, where it is withdrawn from the direct action of the heat.

The fire muft be made to circulate around the boiler by means of a firal chimney; in which cafe none of the heat will be loft, as the whole liquid is furrounded by it, and expofed to its action in an uniform manner.

That the column of fteam which rifes may experience no obftacle in its afcent, the fides of the boiler ought to rife in a perpendicular direction; and the fteam muft be maintained at the fame degree of expanfion till it has reached the refrigeratory. But the fteam rifing freely, and being condenfed by coming into contact with the cool fides of the capital, would fall back into the boiler or body of the fill, if the fides were 
mot inclined in fuch a manner as to make the drops of the liquid, which attach themfelves to them, trickle down into the gutter which conveys them into the worm. I have found by calculation that this inclination ought to be at leaft 75 degrees to the horizon. It is alfo neceffary that the water of the refrigeratory fhould be frequently rencwed; otherwife it will foon acquire the temperature of the fteam, and be no longer able to condenfe it.

Though thefe principles in regard to diftillation are inconteftable, fome modifications muft be made in them for the purpofe of facilitating the operation : by giving to the aperture of the boiler a diameter equal to that of the bafe, the capital becomes very wide; it is confequently neceffary to give it a confiderable height, that its fides may have the inclination of 75 degrees. This conftruction is atrended with two great inconveniences: the firft is, that it renders the capital heavy, clumfy, and expenfive; the fecond, that it makes it difficult to give to the upper edges of the boiler that ftrength neceffary to with tand the effort of the capital. Thefe confiderations induced me to make fome changes in the above conftruction. Thefe changes all relate to the form of the boiler: I make the fides to project a little as they rife, and then bring them nearer to each other towards the top, in fuch a manner that the diameter of the aperture may correfpond to that of the bottom. This form removes the two effects above mentioned, and has the advantage of prefenting a border at the upper part, againft which the bubbles arifing from too ftrong an ebullition may be broken, and thrown back to the centre of the boiler.

Befides this change in the form of the boiler, I thought it proper to take away the refrigeratory with which the capital was covered, and which was attended with the inconvenience of cooling the fleam, and forming a cloud of vapour in the infide, which oppofes its further afienfion.

It may be obferved, that in diftilling by means of a retort in a fand-bath, it will be fufficient to apply a cool body to the retort to produce this effect : frize are immediately feen formed on the fides, and the liquor falls to the bottom of the retort.

If I at firft propofed to preferve the refriceratory, it was becaufe I afcribed to it a part of the effects which depended on a proper conftruetion of the furnace. I, however, afterwards found that a ftill greater effect was obtdined by fupprefing the refrigeratory. Befides, this change was more economical, and occafioned lefs embarraffment.

After this I conceived that the great art of condenfing the vapours was confined to enlarging the beak of the capital, Vol. XI. A a and 
and carefully cooling the worm. By thefe means the va. pours efcape from the ftill with greater facility, as they are admitted into the worm by the fpeedy condenfation of thofe which preceded them.

Thefe different improvements began to be introduced into Languedoc about fifteen years ago. The brothers Argand greatly contributed to make them be adopted. They firt eftablithed fills according to thefe principles, and found them attended with fo much faving, in regard to time and fuel, that from the refults of comparative experiments it has been cftimaled at four-fifths.

I have myfelf fuperintended feveral eftablimments of this kind, where the fame principles were adopted. In my opinion, it is hardly poffible to carry improvement any further; and it is to be withed that this method of diftillation thould become general.

But it is not fo much to the form of the apparatus as to the conftuction of the fire-place, and the proper managenient of the fire, that thefe extraordinary effects are to be alcribed. The pofterior edge of the grate ought to correfiond to the middle of the bottom of the boiler, that the flame may fall upon and heat the whole bottom in an uniform manner. The diftance between the boiler and the grate ought to be from 16 to 18 inches when coals are employed; and the chimney ought to be fpiral.

Befides faving in regard to time, fuel, labour, \&c. this form of apparatus has an influence on the quality of the fpirit. It is far fweeter than any other, and has no empyreumatic tafte; which is a fault almoft infeparable from the common fpirits ufed in commerce: this quality, which renders fpirits of this kind fo fuperior to others, had almoft become caufe of their being rejected, becaufe the inhabitants of the north, whofe principal beverage this liquor is, found it too fweet. It was therefore neceffary to mix it with burnt fpirit, in order to give it a good name. This fiery tafte may be eafily communicated to it by maintaining the diftillation beyond the ufual time. The liquor which paffes over towards the end of the operation has evidently a burnt tafte.

In the arts, it is neceffary to humour the tafte and even the caprice of the confumer ; and what among us is rejected in confequence of its bad tafte, may appear exquifite and de. licious to an inhabitant of the north. Burning liquors, which in the north might be accounted weak, are too powerful for the fenfible nerves of the inhabitants of the fouth. Montefquieu has obferved with great ingenuity, that to give a Mufcovite fenfibility you muft flay him. 
By the comparative expetiments I have been able to make I am convinced that a little more fpirit is obtained by this method than by the old one; the caufe of which is, that the fpirit iffues cool from the apparatus, and fuftains no lofs by evaporation. The diftilleries therefore in which this improved apparatus is employed bave no fenfible fmell of the ipirit.

When wines are diftilled, the operation is carried on till the moment when the liquor which paffes is no longer inflammable.

Wines furnith more or lefs fpirit, according to their degree of ftrength. Very generous wine furnithes a third of its weight. The mean term of the product of sur wines in the fouth is a fourth of the whole: there are fome which furnith a third.

Old wines give better fpirit than the new ; but they furnifh a lefs quantity, efpecially when the decompofition of the faccharine body has been terminated before the diftillation.

What remains in the boiler after the fpirit is extracted is called vina/je: it is a confufed mixture of tartar, colouring matter, dregs, \&cc. This refidum is thrown away as ufelefs; yet by drying it in the air, or in a ftove, very pure alkali might be extracted from it by combution.

In fome diftilleries the vinaffe is acidified, in order to be diftilled, and to extract from it the little vinegar that has been formed in it.

The fpirit is ftronger according as it is mixed with a greater or lefs quantity of water; and as it is of importance in commerce to be able to afcertain eafily the degrees of ftrength, many refearches have been made to difcover the means of determining it.

The diftiller judges of the ftrength of the fpirit by the number, fize, and permanency of the bubbles which are formed when the liquor is thaken : for this purpofe he pours it from one veffel into another, lets it fall from a certain height, or, what is more common, puts it into a long fialk, which is filled two-thirds, and then thakes it violently, keep.ing the mouth thut with his finger. This lalt apparatus is called in French $l a$ fonde.

The proof by combuftion, in whatever manner performed, is very defective. The regulation of 1729 prefcribes putting gunpowder into a fpoon, covering it with liquor, and letting fire to it. The fpirit, if it inflame the powder, is confidered to be of the firft quality : when the contrary happens, it is bad. But liquor of the fame quality inflames, or does not in-

$$
\text { A a } 2
$$
flame, 
Hane, aecording to the proportion employed. A fmall quan. tity always infames; a large one never, becaufe the water which the liquor laves is then fufficient to moilten the gunpowder, and to fecure it from inflammation.

Recourfe bas been had to falt of tartar (carbonate of potafl) for trying the flrength of fpirits. This alkali diffolves in water, but not in alcohol, fo that the latter floats on the folution which is formed.

Thefe methods, more or lefs defective, have rendered it neceffary to try other means capable of determining the ftrength of firit, by afcertaining the fpecific gravity.

A drop of oil poured upon alcohol fixes itfelf on the furface, or is precipitated to the bottom, according to the degree of the frength of the liquor. This method was propofed, and adopted by the Spanifh government in 1770 : it formed the object of a regulation; but it is liable to error, fince the effect depends on the height of the fall, the gravity of the oil, the fize of the drop, the temperature of the atmofphere, the dimentions of the veffels, \&c.

In 1772 this important object was refumed by two able philofophers, Borie and Poujet, of Cette, who made known to the diftillers of Languedoc a new areometer, which they adopted. They applied to it a thermometer, the different degrees of which indicate at every inftant the corrections that ought to be made in the graduation of the areometer, in confequence of the very variable temperature of the atmofphere.

By the help of this areometer, not only may the degree of ftrength be afcertuined, but the fijrit may be carried to any point required; for this purpole different weights are provided. The heavief is marked Dutcb proof, the lighteft ibree-feventbs : if the weight marked Dutch proof be therefore fcrewed to the lower extremity of the thank, and if the inftrument be immerfed in liquor of tbree-leventbs, it will fink a great deal too much, but it may be brought back to Dutch proof by adding four-fevenths of water.

On the other hand, if the weight tbree-fevenths be fcrewed to the fhank, and if the areometer be then immerfed in liquor Dutch proot, it will rife above the laft term, and may be eafily brought back to that degree by adding ftronger alcohol.

When fpirit is difilled for the purpofe of extracting alcohol from it, a balneum marice is commonly employed: the heat is then more gentle, and more uniform, and the product of the diftillation is of a better quality : this product is the common fpirit of wine ufed in commerce.

3d, Tartar. 


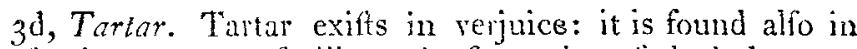
nuft : it concurs to facilitate the formation of alcohol, as we have already obferved from the experinents of Bullion. It depofits itfelf on the fides of the carks in coufequence of reft, and forms there a cruft of greater or lefs thicknefs, rough, with cryftals very badly determined. Some time before the vintage, when the veffels are getting ready for receiving it, the calks are opened, and the tartar is taken out, to be employed in commerce and for various other purpofes.

Tartar is not furnined by all wines in the fame proportion. Red wines give more than the white. The highteft coloured and thickeft generally give the molt.

The colour of the tartar alfo varies very nutch, and it is called red or subite, according as it is produced from either of thefe wines.

This falt is very little foluble in cold water: it is much more fo in boiling water. It fearcely diffolves in the mouth, and refifts the preflure of the tecth.

It is freed from its colouring principle by a fimple procefs, and is then known under the name of cream of tarlar. For this purpole it is diffolved in boiling water, and, when the water is faturated, the folution is put into earthen veficts to cool: as it cools, it precipitates a firatum of cruftals which are already almoft free from colour. Thefe cryflals are again diffolved in boiling water: four or five per cent. of an araitlaceous and fandy hind of earth, found at Muriel, near Montpellier, is diffufed through the folution, and it is then evaporated to a pellicle. On cooling, it precipitates white cryttals, which being expofed in the open air on cloths for fome days, arquire that whitenefs which belongs to cream of tartar. The mother-waters are referved for being employed in new folutions. Such is the method practifel at Montpellier and in its cnvirons, where the principal part of the manufactories of cream of tartar are eftablithed.

The tartar is employed alfo as a flux : it is attended with the double advantage of furnifhing the carbon neceffary for the deoxygenation of the metals, and allo alkali, which is one of the beit fluxes known.

Tartar is purified alfo by calcination. Its acid is decompofed and deftroyed by this procefs, and there remains then nothing but the alkali and the charcoal : the alkali is diffolved in water, the liquor is filtered, and, being then concentrated, that falt known in the fhops under the name of falt of tartar, or carbonate of potafb, is obtained.

The alkali furnifhed by tartar amounts only to one-fourth of its weight. 


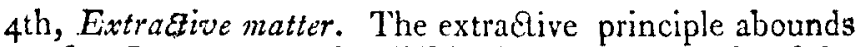
in muft. It appears to be diffolved in it by the help of the fugar; but when the fermentation changes the nature of the faccharine principle, the extractive matter fonfibly decreafes. A porlion brought back then almott to the ftate of fibrine matter is precipitated: the depofit is the more fenfible as the fermentation flackens, and as the alcohol is more abundant. This is what conftitutes in particular the lees. Thefe lees are always mixed with a pretty confiderable quan. tity of tartar, which it envelops.

There always exifts in wine a portion of extractive matter which is in nerfect folution, and from which it may be freed by evaporation. It is mcre abundant in now wines than in old. The older they grow, they feem to be the more comr pletely freed from it.

Thefe lees, after being dried in the fun or in a ftove, are well preffed, and then burnt, to extract that fort of alkali called in commerce wood afbes. The combuttion is effected in a furnace, the fides of which are raifed in proportion as it takes place: the refidum is a prous mafs, of a greenith gray colour, which forms about the thirtieth part of the lees burnt.

Wines are freed from thefe lees by drawing them off, in order to preferve them from acid degeneration.

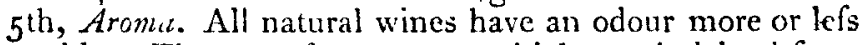
agreeable. There are fome, even, which are indebted for a great part of their reputation to the agreeable odour they exhale. This is the cafe with Burgundy wine. This perfume is loft by too tumultuous a fermentation: it becomes ftronger by age. It rarely exifts in very generous wines; either becaufe it is concealed by the ftrong odour of alcohol, or becaufe the ftrong fermentation which has been neceffary to develop the fpirit has extinguifhed or diffipated it. This aroma does not appear fufceptible of being extracted, to be communicated at pleafure to other fubftances. Heat even feems to deftroy it; for, except the firft liquid which paffes over by diftillation, and which retains a little of the odour peculiar to wine, the fpirit which comes after has no longer the characters that effentially belong to it.

6th, Tbe colouring principle. The colouring principle of wine exitts in the pellicle of the grapes. When the muft is fermented without the $\mathrm{kins}$, the wine is white. This colouring principle does not diffolve in the vintage but when the alcohol is developed in it; and it is only then that the wine becomes coloured. The colour is ftronger according as the fermentation has been more tumultuous, or as it has been left longer in the vat. Mere preffure of the grapes by treading 
treading them, if done with care, may mix with muft a quantity of colouring matter fufficient 10 make the mafs aftune a very intenfe colour. When it is required to obtain wine free from colour, the grapes are collected while the dew is upon them, and they are trod as little as poffible.

The colouring principle is in part precipitated in the cafks along with the tartar and the lees; and when the wine is old, it is not uncommon to fee it entirely free from colour. The colour then depofits itfelf in pellicles on the fides of the veffels, or at the bottom: it is feen floating in the liquid like films, which renter it turbid.

If bottles filled with wine be expofed to the fun, a few days will be fufficient to precipitate the colouring matter in Jarge pellicles; and the wine lofes neither its perfume nor its qualities: I have often made this experiment on the old highly coloured wines of the fouth.

To precipitate the principle of the colour, nothing is neceffary but to pour lithe water into the wine. In this cafe, the lime combines with the malic acid and forms a falt, which appears in the liquor under the form of light flakes. Thefe flakes gradually deporit themiclves, and carry with them all the colouring principle. The depofit is black or white, according to the colour of the wine emplored for the operation. It often happens that wine is fufceptible of forming a precipitate, though it has been completely freed fro.n its colour by a firf depofit; which proves that the principle of the colour bas firong affinity to malate of lime. The coloured precipitate is infoluble both in cold and in warm water. This liquid even produces no change in the colour. Alcohol has fearcely any effect upon it, only it acquires from it a light tint of brown.

The nitric acid diffolves the colouring principle of this precipitate.

When wine has been reduced to the ftate of extract, the alcohol poured over it becomes ftrongly coloured, as well as the water, though in a lefs degree. But, befides the colouring principle which is then diffolved, there is alfo a faccharine extractive principle which facilitates the folution.

The colouring principle, then, does not appear to be of the nature of refins; it prefents all the characters belonging to a very numerous clafs of vegetable products, which approach very near to fecula, without having all their properties. The greater part of colouring principles are of this kind: they are foluble by the affiftance of extractive matter, and when freed from this medium they become fixed in a lating manner, 